Article

\title{
Ranked Choice Voting and Youth Voter Turnout: The Roles of Campaign Civility and Candidate Contact
}

\author{
Courtney L. Juelich ${ }^{1}$ and Joseph A. Coll ${ }^{2, *}$ \\ ${ }^{1}$ Department of Political Science, University of Wisconsin-Stout, Menomonie, WI 54751, USA; \\ E-Mail: juelichc@uwstout.edu \\ 2 Department of Political Science, University of lowa, lowa City, IA 52242, USA; E-Mail: joseph-coll@uiowa.edu \\ * Corresponding author
}

Submitted: 14 December 2020 | Accepted: 15 March 2021 | Published: 15 June 2021

\begin{abstract}
Ranked choice voting (RCV) has become increasing popular in the United States as more cities and states begin allowing voters to rank candidates in order of preference. This change in election system has been linked to increased campaign civility and mobilization, but with little evidence suggesting these benefits lead to increased voter turnout in the general population. This study argues that RCV elections may not increase overall voting but will increase youth voting. Considering young Americans, who have become increasingly pessimistic towards politics and are also heavily reliant on mobilization for participation, this study argues that increased campaign civility and mobilization may work to offset the negative feelings and lack of political engagement that plague young Americans. Using a matched study of individual level voter turnout for seven RCV and fourteen non-RCV local elections from 2013 and 2014, we find that there is no statistical difference in voting rates between RCV and plurality cities for the general public. Yet, in line with our hypotheses, younger voters are more likely to vote in RCV cities. Further, we find that increased contact in RCV elections accounts for a larger portion of the increased voter turnout compared to perceptions of campaign civility. Findings suggest RCV acts as a positive mobilizing force for youth voting through increasing campaign contact.
\end{abstract}

\section{Keywords}

campaign civility; mobilization; ranked choice voting; voter turnout; youth voting

\section{Issue}

This article is part of the issue "The Politics, Promise and Peril of Ranked Choice Voting" edited by Caroline Tolbert (University of lowa, USA).

(C) 2021 by the authors; licensee Cogitatio (Lisbon, Portugal). This article is licensed under a Creative Commons Attribution 4.0 International License (CC BY).

\section{Introduction}

United States federalism gives wide latitude to state and local governments for the administration of their elections. Because of this, the structure of elections can vary drastically across states, counties, and even cities. One such variation is whether elections are conducted under plurality, majority, or preferential voting rules. Most elections conducted in the United States operate under plurality or majority rules. For plurality elections, the candidate with the most votes wins. In majority elections, candidates must be awarded a majority of the votes cast in a single round. If no candidate meets the threshold, runoff elections are held at a later date, in which the top two candidates compete for a simple majority of votes. Preferential voting systems, on the other hand, require the winner receive a majority of votes while not requiring follow up elections. Instead, voters rank candidates for a single office in order of preference at a single time at the voting booth. If no candidate receives a majority, the least popular candidate is eliminated, and all votes cast for that candidate automatically go to the respective voter's second choice (cf. Grofman \& Feld, 2004). This continues until a candidate receives a majority of the votes cast in a round. 
Preferential voting systems have been gaining popularity in recent years, including in the United States (Fortin, 2020), as more US cities and states reform their elections to incorporate systems such as ranked choice voting (RCV). In 2018, Maine used RCV for the first time for midterm elections. Yet, Maine is just one example of RCV in the United States. Five states used RCV for their Democratic primary, six use RCV for overseas voters, and several large cities utilize RCV for local elections (e.g., San Francisco, CA; St. Paul, MN). According to FairVote, a nonprofit, non-partisan RCV advocacy organization, approximately ten million voting age Americans reside in jurisdictions that have adopted $\mathrm{RCV}$, and nearly four hundred RCV elections have been conducted as of September 2020 (FairVote, 2020).

Despite the increased popularity of preferential elections, few studies have investigated the effects of such systems on voter turnout comparatively, and even less so in the context of the United States. Previous studies have found that US elections conducted under preferential voting rules result in more civil campaigning (Donovan, Tolbert, \& Gracey, 2016) and greater campaign mobilization efforts (Bowler, Donovan, \& Brockington, 2003; Smith, 2016). However, only a handful of studies have tested whether this leads to increased voting. Of those that investigate turnout effects, most find no evidence of increased turnout (e.g., McDaniel, 2016), though none have investigated potentially differential affects based on age. Yet, age may be an important demographic worth directly assessing when investigating the participatory effects of preferential elections. Stark differences exist in perceptions of politics and reliance on mobilization efforts by age and generation, with younger, Millennial (born 1981-1996), and Generation Z (1997-2012) voters possessing more pessimistic political outlooks (Dermody \& Hanmer-Lloyd, 2004; Lawless \& Fox, 2015) and a larger reliance on campaign outreach (Dalton, 2015) while less likely to be contacted by campaigns (Nickerson, 2006; Rosenstone \& Hansen, 2003). Because of these factors, it could be that the increased civility and mobilization may be more beneficial for young voters than their older counterparts. That is, preferential elections may offset the pessimistic perceptions of politics among young voters while increasing the chances of being contacted, resulting in increased youth voter turnout.

This study proposes that institutional changes to the electoral system as a result of replacing plurality and majority elections with preferential electoral systems should reduce the incivility of campaigns while increasing campaign contact. As such, switching to preferential elections should increase the rates of political participation among young voters who are particularly disaffected and less likely to be contacted by campaigns. To test whether preferential elections increase youth turnout, and whether increased civility or mobilization are key mechanisms through which preferential elections do so, we leverage the natural variation in electoral systems across cities in the United States. We compare voter turnout, perceptions of civility, and candidate contact efforts between preferential and plurality cities matched on key demographics to determine the extent to which preferential elections increase youth voting and whether civility or mobilization are key mechanisms of that increased turnout.

The remainder of this study will proceed as follows: First, we review the literature surrounding preferential voting. Then we discuss who young voters are and why we expect preferential voting to impact their voting behavior, after which we form our hypotheses regarding the mechanisms and effects of preferential elections. Data, method, and analyses follow. The article ends with a summary of the results.

\section{Preferential Voting Systems: Function and Effects}

Most research on preferential voting draws from European, African, and Asian politics, given the historically limited use of the process in the United States. Reilly (2002) uses case studies from 'divided societies' like Papua New Guinea, Northern Ireland, Sri Lanka, Estonia, and Fiji and compares them to 'non-divided' societies like Australia, parts of Europe and North America. Reilly finds preferential voting better represents the interests of a larger amount of people and leads these interests to becoming a part of major parties' platforms more often than plurality systems. In the context of divided or disaffected societies that Reilly investigates, this is an important electoral and democratic feature of preferential elections which allows those with less political power to become more involved and have more influence within the political process. By giving citizens the chance to rank candidates in order of preference, preferential voting may decrease the chances that one's vote becomes wasted, providing greater individual influence in elections and satisfaction with the process. Reilly's results echoed those of Horowitz (2000) who finds political systems that allow voters to cast multiple preferences promote bargaining, alliances, and inclusion among rival political groups and political elites, leading to better citizen representation.

Farrell and McAllister (2006) assess the satisfaction with democracy across 29 nations, mostly from western Europe with the addition of Australia, New Zealand, Taiwan, and the United States. Their survey results show that preferential voting systems promote a greater sense of fairness about the election and also increase the public's satisfaction with the democratic system as a whole. Farrell and McAllister (2006) also find that preferential elections work to bring together diverse and divided populations, create a more inclusive and cooperative government and party system, and help increase the public's perceptions of external efficacy of their government; giving modern support to the theories outlined by Reilly (2002) and Horowitz (2000). Greater campaign civility and citizen perceptions of fairness in preferential elections has also been observed at the local level in 
the United States. Donovan et al. (2016) and John and Douglas (2017), find that voters in RCV cities rated campaigns as less negative, were more satisfied with campaign conduct, and perceived less criticizing between the candidates (but see Nielson, 2017). Related, using text analysis, a working paper by McGinn (2020) finds that candidate debates are more civil with less negativity under RCV elections. The theoretical story outlined in these articles suggests that preferential voting systems increase civility of campaigns, as candidates now have an incentive to campaign for second and third place and do so by actively not attacking their political opponents or risk alienating their opponents' supporters (see also Drutman, 2020).

Not only has research shown RCV elections to be more civil, but others have shown RCV candidates to engage in more campaign outreach efforts in an attempt to court new or non-supportive voters and expand their base. In support of this, Bowler et al. (2003) find that candidates in preferential voting systems were more likely to try to mobilize voters than those in plurality systems. A report by FairVote shows that citizens of RCV jurisdictions were more likely to be contacted by a campaign, and this contact was also more likely to include in-person contact (Smith, 2016), the most effective form of mobilization (Gerber \& Green, 2000; Green, Gerber, \& Nickerson, 2003a).

Despite the increased mobilization and campaign civility, few articles have demonstrated participatory effects of preferential elections. A working paper by McGinn (2020) suggests that preferential elections may increase voter turnout. In their unpublished study of RCV mobilization effects, Kimball and Anthony (2016) show that RCV does not increase voting but does retain voters between the primary and general elections. Still, others have charged RCV with potentially decreasing turnout or increasing the frequency of under/over votes. Ranking multiple candidates is more difficult and cognitively demanding than selecting only a single preference (Bowler \& Farrell, 1995; Donovan et al., 2019; Kimball \& Kropf, 2016). As such, people may abstain from voting or, when voting, accidentally over/under vote due to not understanding the ranking process. Using survey data, Donovan et al. (2019) find that voters in RCV cities perceived greater difficulty with the voting process than did their counterparts in plurality cities, though not by large margins. Burnett and Kogan (2015) use ballots cast in four California RCV elections and find that 8 to 12 percent of ballots marked the same candidate multiple times. Looking at aggregate turnout data in San Francisco mayoral elections from 1995 to 2011, McDaniel (2016) finds that Black and white individuals vote less in RCV elections.

The evidence presented thus far suggests that preferential elections are more likely to result in the preferred candidate being elected, are more civil, have greater candidate contact, but may not increase voting in the general public and potentially decrease voting for the certain subgroups. Do these results to extend to youth voters? Or will the increased campaign civility and candidate contact under preferential elections increase youth turnout, as we theorize?

\section{Youth Participation and RVC}

Scholars analyzing youth voter turnout in the United States and comparatively have generally agreed that the percentage of young individuals voting has been declining. In studying the period between 1972 (the first year that 18-20-year-olds could vote in the United States) and 2002, Levine and Lopez (2002) find that American youth participation in presidential elections declined in the aggregate by 13 to 15 percentage points. Franklin (2004) argues that lowering the voting age has had the effect of decreasing generational voting across multiple advanced democracies. Related, Holbein and Hillygus (2020, p.3) note that the turnout gap between generations has widened over time, particularly in the United States, with today's youths less likely to become voters compared to earlier generations. Confronted with low youth turnout rates, many argue that that younger generations abstain from voting due to being politically apathetic, lacking a sense of civic duty, being unaware of the political process, and most damningly, are ignorant and indifferent by choice (e.g., Putnam, 2000).

Other scholars argue today's youths are not voting at the same rates as older Americans or earlier cohorts because of perceptions of the political system being unresponsive or corrupt. The end of the 20th century gave rise to increased partisan loyalty and negative media influence that paved the road for increased polarization, Congressional gridlock, and negative partisanship (Abramowitz \& Webster, 2016; Grossmann \& Hopkins, 2016; Mason, 2018). Related, trust in the Government to do the right thing and approval of Congress have been declining rapidly in past decades and are at all-time lows (Pew Research Center, 2019). These stark change in political discourse, trust, and approval directly coincide temporally with the years in which Millennials began developing their political selves. This has resulted in today's youths maturing in an era of intense political polarization, dysfunction, and negativity, resulting in lower levels of political trust and efficacy that has bled over into decreased voting.

Dermody and Hanmer-Lloyd (2004) review evidence of declining political participation among British youths and determine that trust, distrust, and cynicism all feature strongly in determining political engagement. They advocate for youth targeted marketing campaigns that help to increase trust and reduce distrust, which, they argue, should increase the likelihood of youth voting. In the United States, Lawless and Fox (2015) find that the mean-spirited and dysfunctional nature and portrayal of the American political system has led to youths not believing in the ability of elected officials or government to be an effective entity for promoting positive change. 
Young people identified dishonesty, self-centeredness, being argumentative, and being only out for themselves as the most common negative attributes about American politicians. They also find that the youth feel alienated from contemporary American politics. The authors suggest the prevalence of negative campaigning and lack of civil discourse may be especially destructive to youth participation in politics.

Not all scholars are satisfied with the conclusion that younger citizens simply abstain from political participation out of apathy or pessimism. Instead, others began investigating alternative explanations for the youth's apparent apathy. Looking at participation more broadly to include actions such as protesting and petition signing, Dalton (2015) finds that younger members of the electorate are participating, just doing so outside of the institutionalized ways that older generations have participated. Dalton argues older citizens are more likely to be 'duty-based citizens,' defined as one's participation being driven by a sense of needing to perform basic democratic and civic duties, while today's youths are more likely to be 'engaged citizens,' whose participation is based on activism, passion, and campaign mobilization (Dalton, $2008,2015)$. Young people vote in elections not out of duty, but when they are engaged by the issues, campaigns, or candidates (Dalton, 2015; LaCombe \& Juelich, 2019; Lawless \& Fox, 2015; Sloam, 2014). This could be why mobilization and contact efforts can have such a large influence on young voters (Green \& Gerber, 2001), and why youth turnout has declined as parties expend less efforts attracting young voters or engaging with the political issues that young voters support (Endres \& Kelly, 2018; Green et al., 2003b). Because young voters are less likely to vote, candidates and campaigns view them as not worth mobilizing. Additionally, even if campaigns wanted to contact youth voters, their increased mobility and lower homeownership rates makes it more difficult to do so (Nickerson, 2006; Rosenstone \& Hansen, 2003). This literature agrees that the youth see the electoral process as corrupt, non-responsive, and unproductive, but add that, as a result they focus their civic energies from voting to other means of participating absent proper mobilization.

Still, other scholars have turned their focus from internal feelings to political resources and external institutions. Younger Americans have lower levels of resources and voter habituation (Plutzer, 2002), and as such, may be more susceptible to the influences of changes in the electoral environment. In support of this assertion, Holbein and Hillygus (2020) test the effects of pre-registration, same-day registration, and other permissive electoral reforms on youth turnout, finding that young individuals are especially sensitive to changing costs to vote and are more likely to vote when the voting process, particularly registration, is made easier (see also Hanmer, 2009; Leighley \& Nagler, 2013). Coming from the opposite angle, Juelich and Coll (2020) use an index of electoral reforms (Li, Pomante, \& Schraufnagel, 2018) to estimate the effect of more restrictive environments on youth voting and find that younger Americans vote less when electoral reforms are designed in more restrictive ways. This third line of literature acknowledges that young voters have lower efficacy and resources, while demonstrating how altering the rules of the game can alter the extent to which those barriers hinder youth voting.

Although evidence for RCV turnout effects on the general public is mixed, we hypothesize that RCV elections should increase youth voting by decreasing the negativity of elections and increasing candidate contacttwo issues that plague young voters more than their older counterparts-and also because youth behavior is influenced to a greater extent by changes in electoral environments than that of older individuals.

In this article we will propose the following hypotheses:

- Hypothesis 1: Younger voters in RCV cities will be more likely to vote than younger voters in plurality cities.

- Hypothesis 2: The effects of RCV will increase younger voter propensities more than older voter propensities.

- Hypothesis 3: Increased civility will account for part of the increase in youth voter turnout in RCV cities.

- Hypothesis 4: Increased mobilization will account for part of the increase in youth voter turnout in RCV cities.

To visually lay out our hypotheses, Figure 1 shows the expected relationship between electoral systems, civility and mobilization, and youth voter turnout. We expect that preferential voting elections will lead to increased campaign civility and mobilization, which will in turn lead to increased youth voter turnout; while first-past-thepost elections will have less civility and mobilization, and thus, lower youth turnout.

\section{Data and Research Design}

The data used in this study come from two surveys conducted immediately after the 2013 and 2014 November elections in several US cities. Following both elections, telephone interviews were conducted in English and Spanish through random digit dialing via landlines and cellphones by the Rutgers-Eagleton Institute of Politics. The survey was conducted on samples of registered voters in both RCV and plurality cities in the United States. Respondents were chosen randomly within each city, not based on RCV-plurality groupings (i.e., respondents from one city are independently drawn from respondents in other cities). In each survey-year, roughly 2,400 respondents were sampled for a total of roughly 4,800 respondents. Half of survey respondents reside in RCV cities, the other half in plurality cities. The cities and 


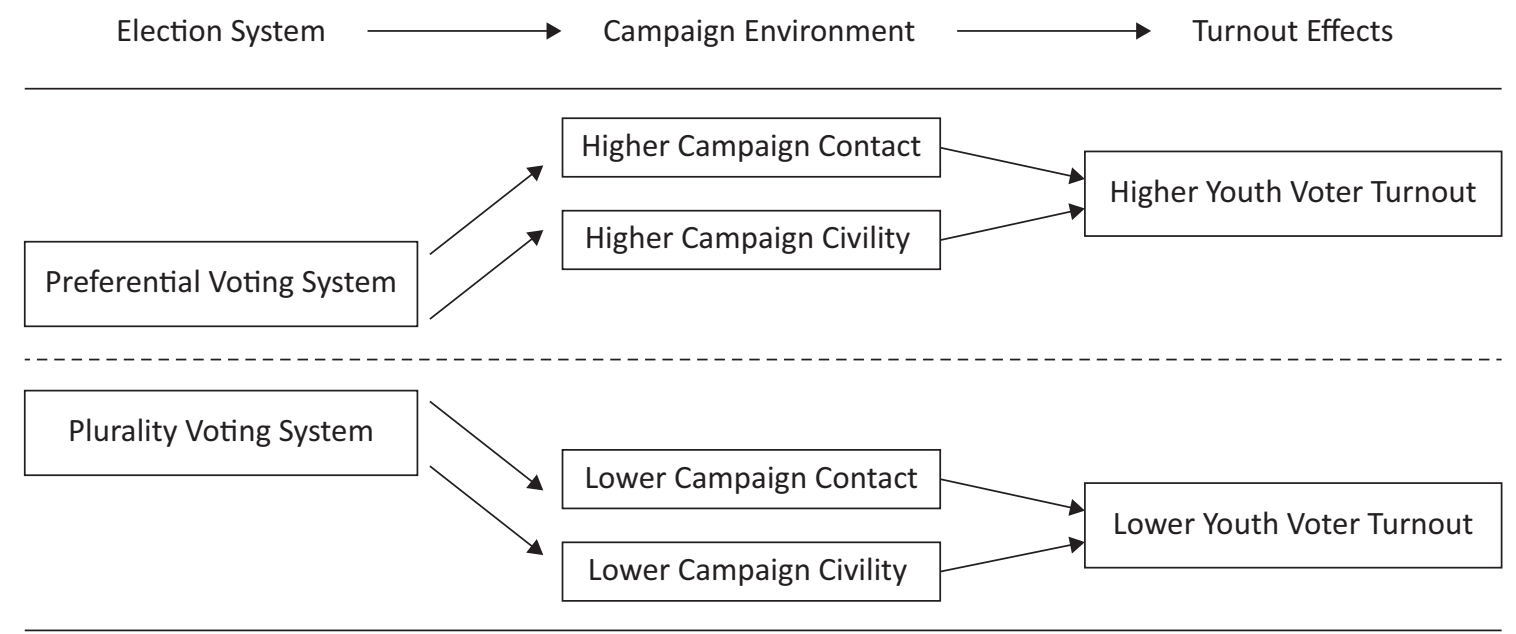

Figure 1. Theoretical diagram.

their RCV/plurality designation can be seen in Table 1 . In parentheses beneath each city is the number of respondents from that city, as well as the city's population for comparability (for a more complete list of city demographics, see the Supplementary File, Appendix C, Table C3).

The chosen RCV cities represent some of the largest local election districts that used RCV in the United States (during the 2013-2014 elections, when data were collected), as well as some of the most frequently studied RCV jurisdictions (e.g., Burnett \& Kogan, 2015; Donovan et al., 2016, 2019; McDaniel, 2016). To find comparable control cases, plurality cities were matched on population size, racial and ethnic composition, political characteristics, US region, and socio-economic conditions. Though there are undoubtedly some differences between the treatment and control cities, we believe that this approach can help mitigate concerns of noncomparability between treatment (RCV) and control (plurality) cities for three key reasons.

First, most RCV cities have multiple control cities, allowing for greater leverage in the control group. Second, with the exception of the two RCV cities in Minnesota, all RCV cities are in the same state as their plurality counterparts, with many in the same county. Though between-city differences may remain, most localities are operating under the same county and state level influences (e.g., county and state level participatory culture, election resources and regulations). As such, comparing voter turnout in RCV cities to plurality cities matched on important characteristics and that are operating in similar electoral environments helps control

Table 1. RCV cities and their plurality matches.

\begin{tabular}{|c|c|c|c|c|}
\hline \multirow{2}{*}{$\begin{array}{l}\text { RCV Cities } \\
\text { Berkeley, CA } \\
(112,116 \mathrm{k})\end{array}$} & \multicolumn{4}{|c|}{ Matched Plurality Cities } \\
\hline & $\begin{array}{l}\text { Alameda, CA } \\
(101,76 k)\end{array}$ & & & \\
\hline $\begin{array}{l}\text { Cambridge, MA } \\
(190,107 k)\end{array}$ & $\begin{array}{l}\text { Lowell, MA } \\
(99,108 k)\end{array}$ & $\begin{array}{l}\text { Worcester, MA } \\
(94,119 k)\end{array}$ & & \\
\hline $\begin{array}{l}\text { Minneapolis, MN } \\
(790,394 k)\end{array}$ & $\begin{array}{l}\text { Boston, MA } \\
(255,640 k)\end{array}$ & $\begin{array}{l}\text { Seattle, WA } \\
(249,648 k)\end{array}$ & $\begin{array}{l}\text { Tulsa, OK } \\
(261,396 k)\end{array}$ & \\
\hline $\begin{array}{l}\text { Oakland, CA } \\
(670,402 k)\end{array}$ & $\begin{array}{l}\text { Anaheim, CA } \\
(99,343 k)\end{array}$ & $\begin{array}{l}\text { Santa Clara, CA } \\
(144,120 k)\end{array}$ & $\begin{array}{l}\text { Santa Ana, CA } \\
(99,331 k)\end{array}$ & $\begin{array}{l}\text { Stockton, CA } \\
(109,297 k)\end{array}$ \\
\hline $\begin{array}{l}\text { San Francisco, CA } \\
(149,829 \mathrm{k})\end{array}$ & $\begin{array}{l}\text { San Jose, CA } \\
(197,986 k)\end{array}$ & & & \\
\hline $\begin{array}{l}\text { San Leandro, CA } \\
(383,87 k)\end{array}$ & $\begin{array}{l}\text { Richmond, CA } \\
(338,106 \mathrm{k})\end{array}$ & & & \\
\hline $\begin{array}{l}\text { St. Paul, MN } \\
(196,292 k)\end{array}$ & $\begin{array}{l}\text { Cedar Rapids, IA } \\
(106,128 k)\end{array}$ & $\begin{array}{l}\text { Des Moines, IA } \\
(90,207 k)\end{array}$ & & \\
\hline Total RCV:2,490 & Total Plurality: 2,241 & & Grand Total:4,731 & \\
\hline
\end{tabular}


for unobserved factors influencing turnout. Taking this within-country (and usually within-state, if not withincounty) approach provides a stronger set of control cases and claim to causality than would taking a cross-national approach where treatment and control cases may differ drastically on unobservable characteristics. Last, though the type of preferential voting differs by city, the data at hand do not allow us to differentiate by preferential style. However, this should not be an issue for our analyses, as increased civility and mobilization has been found across different preferential election types (e.g., Donovan et al., 2016; John \& Douglas, 2017; Kimball \& Kropf, 2016; McGinn, 2020; Smith, 2016). For brevity, we use RCV to denote preferential cities and plurality to denote plurality cities.

Using individual level data provides three advantages over aggregate data for this study. First, studies using aggregate data often assume that the presence of an electoral reform being correlated with increased proportions of demographic group participation means that individuals from that group are more likely to participate due to that reform. However, inferring individual behavior from aggregate patterns may result in an ecological fallacy; just because a group average may be higher or lower than others does not conclude that random individuals in that group are more or less likely to be affected. Second, using individual level data allows us to further control for individual factors that may affect whether someone decides to vote. When using aggregate data, researchers cannot control for individual differences in characteristics that may lead individuals of a demographic group to participate at different rates than members of a different demographic group or those in the same group. Third, being able to control for individual level differences helps mitigate concerns of non-comparability across treatment and control groups. Comparing individual level voting behavior in cities chosen to control for aggregate level factors while also controlling for individual level factors helps mitigate concerns of non-comparability across cases, even if the cities chosen are not perfect control cases.

With that being said, there are a few limitations to the data. First, the data is several years old at this point. Thus, it is worth considering the extent to which these findings can be generalized to today. Yet, it is still worth documenting whether RCV affects youth voting behavior and why, particularly considering its rising popularity. Second, the survey is of only registered voters and asks respondents to self-report voting. Potentially because of this, average voter turnout in the sample is substantially higher than would usually be expected, at 83 percent for the full sample, 85 percent for RCV cities, and 82 percent for plurality cities $(p=0.002)$. Turnout in these elections typically ranged 33 to 45 percent. While this turnout is substantially higher than expected, working with a sample with such high self-reported turnout may make finding any effects for RCV on youth voting more difficult due to high turnout rates essentially 'capping' potential effects. Thus, this higher-than-actual turnout may bias against finding any evidence of RCV effects. Third, only RCV cities from three states (California, Massachusetts, and Minnesota) were used as treatment groups, with the control groups intentionally being similar in politi$\mathrm{cal}$, demographic, and geographic features. Though the city-as-cases approach is beneficial in controlling for unobserved factors, it also limits the generalizability of this study.

\section{Results}

First, to evaluate the effect of RCV on overall turnout, we turn to Table 2. Table 2 reports a series of logistic regression models, where the dependent variable is whether the respondent voted in their local election. Respondents were asked: "Did you vote in the local election last Tuesday in [CITY]?" Possible answers were "no," "yes," "don't know," and "refused" (missing recoded to not having voted to retain statistical precision, results robust to alternative coding schemes, available at request). Each model includes two measures of socio-economic status: Income ( 1 = less than $\$ 10,000,9=$ greater than $\$ 150,000)$ and Education ( 1 = high school graduate or less, $4=$ post-graduate degree); a variable denoting whether the respondent is a Female $(1=$ female, $0=$ male); two variables for race, whether the respondent is Black ( 1 = Black, non-Hispanic, $0=$ not Black) or is another race besides white or Black, non-Hispanic (Other, 1 = other race, $0=$ not another race) with white, non-Hispanic respondents as the reference group; a variable denoting ethnicity (Hispanic, 1 = Hispanic, 0 = non-Hispanic); two measures for partisanship, whether the respondent identifies as a Democrat ( $1=$ Democrat, $0=$ other) or Republican ( $1=$ Republican, $0=$ other), with independents as the reference group; and a measure of interest in local politics (Political Interest, 1 = high interest, $0=$ low interest). To deal with heterogeneity and spatial dependence, each estimation is computed with robust standard errors clustered by city. Results are robust to the inclusion of city fixed effects (available at request). Last, an indicator for which survey-year is included to control for potential differences across surveys and years.

Past the basic specifications, we alter each model to test our hypotheses. Models 2, 4, and 5 include an indicator for whether the respondent lives in a RCV jurisdiction $(R C V, 1=R C V$ city, $0=$ plurality city). Models 1 and 2 include a covariate for Age (18-99) and Age Squared (324-9801). To more precisely test whether RCV elections encourage participation of today's youths, models 3 and 4 swap the covariates of age and age squared for an indicator variable of whether the respondent is above/below 35 and model 5 subsamples only those individuals below the age of 35 as a robustness check. We use 35 as the age cutoff to capture the generational effects that have altered today's youth participation (e.g., their increased political cynicism as a result of 
the negative and hyper-partisan political circumstances during their upbringing, as discussed earlier), as well as to ensure a large enough group of young Americans to compare to older Americans. This age cutoff captures all those in the Millennial and Generation Z generations, with 'youths'/'young' used for brevity to refer to this group. Additional robustness checks using a continuous measure of age, using alternative generational cutoffs, and varying age categories all further support our find- ings (see Supplementary File, Appendix B, Tables B1 and $B 2$, and Figure B1; summary statistics for all variables presented in this study are shown in the Supplementary File, Appendix C, Table C1).

Model 1 in Table 2 acts a baseline voter turnout model for reference. Model 2 tests whether rank choice voting elections increase turnout by including a covariate for whether the election is conducted using RCV. The coefficient is positive but insignificant at conventional

Table 2. Age, election type, and self-reported turnout.

\begin{tabular}{|c|c|c|c|c|c|}
\hline & $\begin{array}{c}\text { Model } 1 \\
\text { Base model } \\
\text { b/se }\end{array}$ & $\begin{array}{l}\text { Model } 2 \\
\text { RCV } \\
\text { b/se }\end{array}$ & $\begin{array}{c}\text { Model } 3 \\
\text { Youth + RCV } \\
\text { b/se }\end{array}$ & $\begin{array}{c}\text { Model } 4 \\
\text { Youth } \times \text { RCV } \\
\text { b/se }\end{array}$ & $\begin{array}{c}\text { Model } 5 \\
\text { Youth subsample } \\
\text { b/se }\end{array}$ \\
\hline \multicolumn{6}{|l|}{ Voted } \\
\hline RCV & & $\begin{array}{c}0.306 \\
(0.220)\end{array}$ & $\begin{array}{c}0.331 \\
(0.222)\end{array}$ & $\begin{array}{c}0.155 \\
(0.218)\end{array}$ & $\begin{array}{l}0.604^{* *} \\
(0.291)\end{array}$ \\
\hline Youth & & & $\begin{array}{l}-1.117^{* * *} \\
(0.123)\end{array}$ & $\begin{array}{l}-1.334^{* * *} \\
(0.136)\end{array}$ & \\
\hline Youth $\times$ RCV & & & & $\begin{array}{c}0.445^{*} \\
(0.230)\end{array}$ & \\
\hline Age & $\begin{array}{l}0.103^{* * *} \\
(0.009)\end{array}$ & $\begin{array}{l}0.102 * * * \\
(0.010)\end{array}$ & & & \\
\hline Age Squared & $\begin{array}{l}-0.001^{* * *} \\
(0.000)\end{array}$ & $\begin{array}{l}-0.001 * * * \\
(0.000)\end{array}$ & & & \\
\hline Education & $\begin{array}{l}0.299 * * * \\
(0.055)\end{array}$ & $\begin{array}{l}0.277^{* * *} \\
(0.054)\end{array}$ & $\begin{array}{l}0.284^{* * *} \\
(0.054)\end{array}$ & $\begin{array}{l}0.282^{* * *} \\
(0.055)\end{array}$ & $\begin{array}{c}0.195 \\
(0.162)\end{array}$ \\
\hline Female & $\begin{array}{c}0.096 \\
(0.104)\end{array}$ & $\begin{array}{c}0.098 \\
(0.103)\end{array}$ & $\begin{array}{c}0.085 \\
(0.107)\end{array}$ & $\begin{array}{c}0.087 \\
(0.107)\end{array}$ & $\begin{array}{c}0.190 \\
(0.184)\end{array}$ \\
\hline Income & $\begin{array}{c}0.038 \\
(0.033)\end{array}$ & $\begin{array}{c}0.041 \\
(0.032)\end{array}$ & $\begin{array}{c}0.031 \\
(0.032)\end{array}$ & $\begin{array}{c}0.033 \\
(0.032)\end{array}$ & $\begin{array}{c}0.055 \\
(0.049)\end{array}$ \\
\hline Employed & $\begin{array}{c}0.049 \\
(0.144)\end{array}$ & $\begin{array}{c}0.043 \\
(0.142)\end{array}$ & $\begin{array}{c}-0.060 \\
(0.144)\end{array}$ & $\begin{array}{c}-0.061 \\
(0.144)\end{array}$ & $\begin{array}{c}0.136 \\
(0.363)\end{array}$ \\
\hline Black & $\begin{array}{c}0.046 \\
(0.158)\end{array}$ & $\begin{array}{c}0.032 \\
(0.157)\end{array}$ & $\begin{array}{c}-0.038 \\
(0.154)\end{array}$ & $\begin{array}{c}-0.041 \\
(0.156)\end{array}$ & $\begin{array}{c}0.086 \\
(0.291)\end{array}$ \\
\hline Asian & $\begin{array}{l}-0.159 \\
(0.149)\end{array}$ & $\begin{array}{c}-0.168 \\
(0.152)\end{array}$ & $\begin{array}{l}-0.312^{* *} \\
(0.151)\end{array}$ & $\begin{array}{l}-0.338^{* *} \\
(0.153)\end{array}$ & $\begin{array}{c}-0.290 \\
(0.323)\end{array}$ \\
\hline Other & $\begin{array}{l}-0.274 \\
(0.257)\end{array}$ & $\begin{array}{l}-0.280 \\
(0.253)\end{array}$ & $\begin{array}{c}-0.351 \\
(0.229)\end{array}$ & $\begin{array}{l}-0.330 \\
(0.230)\end{array}$ & $\begin{array}{l}-0.852 \\
(0.555)\end{array}$ \\
\hline Hispanic & $\begin{array}{l}-0.163 \\
(0.311)\end{array}$ & $\begin{array}{c}-0.128 \\
(0.308)\end{array}$ & $\begin{array}{c}-0.261 \\
(0.293)\end{array}$ & $\begin{array}{l}-0.244 \\
(0.295)\end{array}$ & $\begin{array}{l}-0.295 \\
(0.407)\end{array}$ \\
\hline Democrat & $\begin{array}{c}0.141 \\
(0.108)\end{array}$ & $\begin{array}{c}0.125 \\
(0.108)\end{array}$ & $\begin{array}{c}0.186 * \\
(0.110)\end{array}$ & $\begin{array}{c}0.177 \\
(0.109)\end{array}$ & $\begin{array}{c}0.275 \\
(0.237)\end{array}$ \\
\hline Republican & $\begin{array}{c}0.036 \\
(0.200)\end{array}$ & $\begin{array}{c}0.065 \\
(0.200)\end{array}$ & $\begin{array}{c}0.125 \\
(0.208)\end{array}$ & $\begin{array}{c}0.120 \\
(0.209)\end{array}$ & $\begin{array}{c}0.309 \\
(0.537)\end{array}$ \\
\hline Political Interest & $\begin{array}{l}1.187^{* * *} \\
(0.110)\end{array}$ & $\begin{array}{l}1.208^{* * *} \\
(0.111)\end{array}$ & $\begin{array}{l}1.298^{* * *} \\
(0.114)\end{array}$ & $\begin{array}{l}1.305^{* * *} \\
(0.113)\end{array}$ & $\begin{array}{l}1.320 * * * \\
(0.238)\end{array}$ \\
\hline Constant & $\begin{array}{l}-3.998 * * * \\
(0.388)\end{array}$ & $\begin{array}{l}-4.078 * * * \\
(0.341)\end{array}$ & $\begin{array}{l}-0.586 * * * \\
(0.214)\end{array}$ & $\begin{array}{l}-0.507^{* *} \\
(0.216)\end{array}$ & $\begin{array}{l}-2.041 * * * \\
(0.579)\end{array}$ \\
\hline Observations & 4731 & 4731 & 4731 & 4731 & 473 \\
\hline
\end{tabular}

Notes: Logistic regression with robust and clustered(city) standard errors; ${ }^{*} 0.1{ }^{* *} 0.05^{* * *} 0.01$. Year fixed effects included but omitted for space. 
levels, doing little to solve the debate over the participatory effects of rank choice voting.

Absent any general population effects, we move on to test our first hypothesis of RCV increasing youth voting. Model 3 in Table 2 changes the age covariates for an indicator whether the individual is under 35. Unsurprisingly, younger individuals are less likely to vote compared to older individuals (Franklin, 2004). When we interact whether the respondent is under 35 with whether they live in an RCV city (model 4), a different story emerges. Though younger individuals are less likely to vote in both RCV and non-RCV cities than older individuals, they are significantly more likely to vote in RCV cities compared to younger individuals in plurality elections. These results are graphically depicted in Figure 2, which is a coefficient plot displaying the probability of voting across election type and age group with confidence intervals varying from 90 to 99 percent levels. The probability of voting increases from 77 to 86 percent between non-RCV and RCV cities for young voters, a difference of nine percentage points. These results are further supported when we subsample only young voters (model 5). For older individuals, no statistically significant difference in voting propensities across election type is found. These results confirm hypotheses 1 and 2, that younger individuals will vote more in RCV elections than youths under plurality elections and gain a larger increase to voting in RCV elections than older individuals. With younger voters more likely to vote in RCV elections, but older individuals not affected, this evidence also suggests that RCV may work to lessen the age gap in voter turnout. But are more civil campaigns and greater candidate contact the forces that separate youths between RCV and plurality elections, as theorized here?
To determine the mediational impact of civil campaigning and candidate contact on the relationship between youth turnout and preferential voting systems, this study uses the causal steps approach popularized by Baron and Kenny (1986). The causal steps approach uses three equations to establish a mediating relationship. The first tests for a relationship between the independent variable and the dependent variable (direct effect) to determine if there exists a relationship to be mediated. This relationship was established in models 4 and 5 in Table 2. The second tests for a relationship between the independent variable and the mediator to establish a mediation pathway. The third equation reexamines the relationship between the independent and dependent variables while including the mediator variable, with differences in the effect of the independent variable assumed to be caused by the mediator variable (indirect effect). If the effect of the independent variable is decreased or rendered insignificant, the relationship is said to partially or fully mediated.

This study uses three proxy measures for campaign (in)civility-candidate-to-candidate criticism, dissatisfaction with the candidates, and campaign negativityand one for campaign contact-whether the respondent was contacted by a campaign. To measure the degree of Criticism in the election, respondents were asked: "Thinking about the [CITY] election, how much time would you say the candidates spent criticizing their opponent?" The proposed answers were: "A great deal of time," "some of the time," "not too much," "not at all." The variable is coded so that higher values represent greater levels of criticism. For Dissatisfaction, respondents were asked: "How satisfied were you with the choices of candidates for mayor in this recent [CITY]

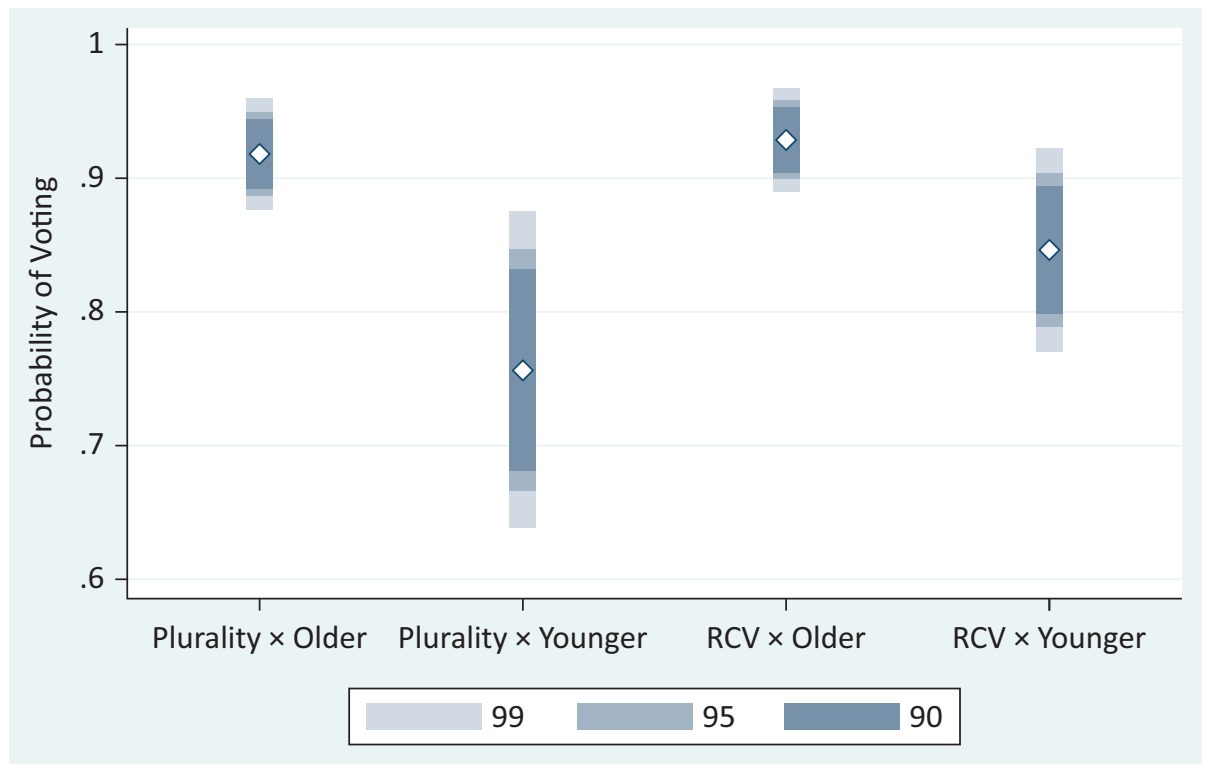

Figure 2. Effect of election type on self-reported voting. Notes: Estimations of logistic coefficients calculated with all other variables held at their means/respective values; robust and clustered(city) errors and year fixed effects employed; 90-99 percent confidence intervals shown. 
election?" The proposed answers were: "Very satisfied," "fairly satisfied," "not very satisfied," "not at all satisfied." Voluntary answers were: "No opinion" and "refusal." The variable was reverse coded so that higher values represent greater Dissatisfaction.

The third measure of campaign civilityNegativity -is constructed from three related questions. Respondents were first asked: "Do you believe the campaigns this year were more negative, less negative, or about the same compared to other recent political contests?" The proposed answers were: "more," "less," and "about the same." Two follow-up questions were asked: "Was it a lot more negative, or just a little more negative?" and "Was it a lot less negative, or a just a little less negative?" Their options were: "a lot" and "a little." Respondents could also respond "don't know" and "refuse." Because few respondents reported the election being a lot less(more) negative, answers were coded into a single variable ranging from Less Negative, About the Same, More Negative, with higher values representing more negativity. Results are robust to using the five-point version that results from distinguishing between those who saw elections are somewhat and a lot less(more) negative (available upon request).
The measure of campaign contact is derived from a question that asked: "During the recent local election, did a candidate or anyone from a local city campaign contact you to persuade you how to vote either by phone, mail, in person or over the Internet?" Respondents could answer "yes" or "no," or volunteer "don't know" or "refusal." The question asks whether a candidate/campaign contacted the respondent by any of the above means to persuade them how to vote. To the extent that respondents were contacted for nonvote-persuasion reasons (e.g., direct mobilization without attempting to change the voters intended vote choice) and answered no on the contact question, this potentially biases the study against finding any effects of contact. Contacted voters are more likely to vote (Gerber \& Green, 2000; Rosenstone \& Hansen, 2003). If a voter is contacted for non-persuasion reasons, answered "no" for contact due to it asking about persuasion of vote choice, but still voted, the result will be an under-estimation of the effect of candidate contact on voter turnout.

Tables 3 and 4 show the results of the causal steps approach. In each table, the first model replicates model 4 from Table 2 for reference of the effect

Table 3. Age, election type, and self-reported turnout: The roles of civility and contact (1/2).

\begin{tabular}{|c|c|c|c|c|c|}
\hline & $\begin{array}{c}1 \\
\text { Base model }\end{array}$ & $\begin{array}{l}2 \\
\text { Predicting } \\
\text { perceived } \\
\text { criticism }\end{array}$ & $\begin{array}{l}3 \\
\text { Predicting turnout } \\
\text { controlling for } \\
\text { perceived criticism }\end{array}$ & $\begin{array}{c}4 \\
\text { Predicting } \\
\text { perceived } \\
\text { dissatisfaction }\end{array}$ & $\begin{array}{c}5 \\
\text { Predicting turnout } \\
\text { controlling for } \\
\text { perceived } \\
\text { dissatisfaction }\end{array}$ \\
\hline & $\mathrm{b} / \mathrm{se}$ & $\mathrm{b} / \mathrm{se}$ & $\mathrm{b} / \mathrm{se}$ & $\mathrm{b} / \mathrm{se}$ & $\mathrm{b} / \mathrm{se}$ \\
\hline RCV & $\begin{array}{c}0.155 \\
(0.218)\end{array}$ & $\begin{array}{c}-0.431 \\
(0.275)\end{array}$ & $\begin{array}{c}0.245 \\
(0.220)\end{array}$ & $\begin{array}{c}-0.066 \\
(0.333)\end{array}$ & $\begin{array}{c}0.096 \\
(0.217)\end{array}$ \\
\hline Youth & $\begin{array}{l}-1.334 * * * \\
(0.136)\end{array}$ & $\begin{array}{c}0.192 \\
(0.135)\end{array}$ & $\begin{array}{l}-1.323 * * * \\
(0.151)\end{array}$ & $\begin{array}{c}-0.178 \\
(0.184)\end{array}$ & $\begin{array}{l}-1.332 * * * \\
(0.135)\end{array}$ \\
\hline Youth $\times$ RCV & $\begin{array}{c}0.445^{*} \\
(0.230)\end{array}$ & $\begin{array}{c}0.224 \\
(0.143)\end{array}$ & $\begin{array}{c}0.503^{* *} \\
(0.235)\end{array}$ & $\begin{array}{c}0.281 \\
(0.262)\end{array}$ & $\begin{array}{l}0.487^{* *} \\
(0.211)\end{array}$ \\
\hline Criticism of other candidates & & & $\begin{array}{l}0.134^{* *} \\
(0.067)\end{array}$ & & \\
\hline Satisfaction of campaign & & & & & $\begin{array}{l}-0.195^{* * *} \\
(0.069)\end{array}$ \\
\hline Controls & $\sqrt{ }$ & $\sqrt{ }$ & $\sqrt{ }$ & $\sqrt{ }$ & $\sqrt{ }$ \\
\hline Constant & $\begin{array}{l}-0.507^{* *} \\
(0.216)\end{array}$ & & $\begin{array}{c}-0.635^{* *} \\
(0.289)\end{array}$ & & $\begin{array}{c}0.095 \\
(0.325)\end{array}$ \\
\hline $\begin{array}{l}\text { Constant } \\
\text { Cut } 1\end{array}$ & & $\begin{array}{c}-0.655^{*} \\
(0.376)\end{array}$ & & $\begin{array}{l}-1.444 * * * \\
(0.501)\end{array}$ & \\
\hline $\begin{array}{l}\text { Constant } \\
\text { Cut } 2\end{array}$ & & $\begin{array}{c}0.490 \\
(0.361)\end{array}$ & & $\begin{array}{l}1.070 * * \\
(0.507)\end{array}$ & \\
\hline $\begin{array}{l}\text { Constant } \\
\text { Cut } 3\end{array}$ & & $\begin{array}{l}2.058 * * * \\
(0.489)\end{array}$ & & $\begin{array}{l}2.623^{* * *} \\
(0.581)\end{array}$ & \\
\hline Observations & 4731 & 4338 & 4338 & 4505 & 4505 \\
\hline
\end{tabular}

Notes: Logistic (models 1, 3, and 5) and ordered logistic regression (models 2 and 4) with robust and clustered(city) standard errors. $* 0.1 * * 0.05 * * * 0.01$. Year/survey fixed effects employed. Control variables omitted to save space. 
Table 4. Age, election type, and self-reported turnout: The roles of civility and contact (2/2).

\begin{tabular}{|c|c|c|c|c|c|}
\hline & $\begin{array}{c}1 \\
\text { Base model }\end{array}$ & $\begin{array}{c}2 \\
\text { Predicting } \\
\text { perceived } \\
\text { negativity }\end{array}$ & $\begin{array}{c}3 \\
\text { Predicting turnout } \\
\text { controlling for } \\
\text { perceived negativity }\end{array}$ & $\begin{array}{c}4 \\
\text { Predicting } \\
\text { mobilization }\end{array}$ & $\begin{array}{l}5 \\
\text { Predicting turnout } \\
\text { controlling for } \\
\text { mobilization }\end{array}$ \\
\hline & $\mathrm{b} / \mathrm{se}$ & $\mathrm{b} / \mathrm{se}$ & $\mathrm{b} / \mathrm{se}$ & $\mathrm{b} / \mathrm{se}$ & b/se \\
\hline \multicolumn{6}{|l|}{ main } \\
\hline RCV & $\begin{array}{c}0.155 \\
(0.218)\end{array}$ & $\begin{array}{l}-1.040^{* * *} \\
(0.339)\end{array}$ & $\begin{array}{c}0.111 \\
(0.203)\end{array}$ & $\begin{array}{c}0.076 \\
(0.237)\end{array}$ & $\begin{array}{c}0.117 \\
(0.190)\end{array}$ \\
\hline Youth & $\begin{array}{l}-1.334^{* * *} \\
(0.136)\end{array}$ & $\begin{array}{l}-0.367^{* *} \\
(0.164)\end{array}$ & $\begin{array}{l}-1.352^{* * *} \\
(0.139)\end{array}$ & $\begin{array}{l}-0.773^{* * *} \\
(0.182)\end{array}$ & $\begin{array}{l}-1.246^{* * *} \\
(0.153)\end{array}$ \\
\hline Youth $\times$ RCV & $\begin{array}{c}0.445^{*} \\
(0.230)\end{array}$ & $\begin{array}{l}0.708^{* * *} \\
(0.207)\end{array}$ & $\begin{array}{c}0.473^{* *} \\
(0.237)\end{array}$ & $\begin{array}{c}0.555^{* *} \\
(0.243)\end{array}$ & $\begin{array}{c}0.370 \\
(0.237)\end{array}$ \\
\hline Campaign negativity & & & $\begin{array}{l}-0.184 \\
(0.150)\end{array}$ & & \\
\hline Contacted & & & & & $\begin{array}{l}0.939 * * * \\
(0.154)\end{array}$ \\
\hline Controls & $\sqrt{ }$ & $\sqrt{ }$ & $\sqrt{ }$ & $\sqrt{ }$ & $\sqrt{ }$ \\
\hline Constant & $\begin{array}{l}-0.507^{* *} \\
(0.216)\end{array}$ & & $\begin{array}{l}-0.149 \\
(0.416)\end{array}$ & $\begin{array}{l}-0.798^{* * *} \\
(0.247)\end{array}$ & $\begin{array}{l}-0.822^{* * *} \\
(0.194)\end{array}$ \\
\hline $\begin{array}{l}\text { Constant } \\
\text { Cut } 1\end{array}$ & & $\begin{array}{l}-1.558^{* * *} \\
(0.282)\end{array}$ & & & \\
\hline $\begin{array}{l}\text { Constant } \\
\text { Cut } 2\end{array}$ & & $\begin{array}{l}1.749 * * * \\
(0.326)\end{array}$ & & & \\
\hline Observations & 4731 & 4731 & 4731 & 4689 & 4689 \\
\hline
\end{tabular}

Notes: Logistic (models 1, 3, and 5) and ordered logistic regression (models 2 and 4) with robust and clustered(city) standard errors. $* 0.1 * * 0.05 * * * 0.01$. Year/survey fixed effects employed. Control variables omitted to save space.

of RCV on youth voting behavior. Following this, each subsequent model either tests whether RCV is related to the mediating variables (models 2 and 4 in both tables) or how the inclusion of the mediator affects the relationship between RCV and youth voting (models 3 and 5 in both tables). In the models predicting the relationship between RCV and the respondent's perception of candidate-candidate criticism, campaign negativity, and their dissatisfaction with candidates, ordered logistic regression is used given the dependent variables of Criticism and Satisfaction range from 1 to 4 , and Negativity ranges from 1 to 3 (results robust to the use of ordinary least squares regression and multinomial logistic regression, available upon request). The models that predict turnout controlling for the different mediators use logistic regression, as does the model predicting candidate contact. Otherwise, all model specifications are the same as used in Table 2. For space concerns, control variables are omitted (see Tables B3.1 and B3.2 in Appendix B, Supplementary File).

Starting with Table 3, the interactions between residing in an RCV jurisdiction and being under the age of 35 are not significantly related to feelings of criticism (model 2) or dissatisfaction (model 4), suggesting younger voters do not perceive more criticism or dissat- isfaction than older votes in RCV elections or younger voters in plurality areas, as well as suggesting a lack of a mediation pathway. Controlling for level of criticism (model 3) and dissatisfaction (model 5) increases the effects of RCV elections on youth voting, though by unsubstantial amounts.

The last measure of campaign civility, campaign negativity, is reported in models 2 and 3 in Table 4 . Unlike the previous measures, the interaction term is statistically significant, suggesting a relationship between RCV elections, young or old voters, and perceptions of campaign negativity. Further analyses reveal that young voters do not change their perceptions of campaign negativity across election jurisdictions. However, older voters find RCV elections less negative, though by an unsubstantial amount, providing some evidence against the argument that the more civil nature of RCV elections may be attracting young voters (see Supplementary File, Appendix B, Figure B2). Does negativity moderate the relationship between election type, age, and voting? Model 3, which includes the interaction term and the measure of campaign negativity to predict voter turnout, suggests not. The covariate for negativity is statistically insignificant and the relationship between the interaction term and the dependent variable is strengthened. 
Why is the relationship of interest related to campaign negativity, but negativity does not mediate the relationship? Further analyses reveal that negativity is not related to the likelihood one votes in the elections under study (see Supplementary File, Appendix B, Tables B4 and B5). The evidence presented thus far suggests that increased civility in RCV elections does not account for increased youth voting in RCV elections.

Besides campaign civility, RCV elections have also been found to have increased contact efforts (Bowler et al., 2003). Is this increased contact leading more youths to the polls in RCV localities? Model 4 in Table 4 suggests that there may be relationship between RCV elections, young or old voters, and increased campaign contact. Young voters are twelve percentage points more likely to be contacted if they reside in an RCV jurisdiction than youths in plurality areas, while no significant effect was found for older voters (see Supplementary File, Appendix B, Figure B3). Does this increased youth contact account for increased youth voting? Model 5 suggests that campaign contact may substantially reduce the relationship between RCV elections, young voters, and voter turnout. The interaction coefficient has decreased by nearly 17 percent and is now insignificant, while the contact covariate is statistically significant. This suggests that mobilization may account for a substantial portion of the increased youth turnout in RCV elections.

Though popular, the causal step approach has been criticized as a procedure for establishing mediation, partially due to its strong but untested assumptions and difficulties being extended to non-linear models (Imai, Keele, Tingley, \& Yamamoto, 2011). As an additional robustness check, models were re-estimated using the non-parametric approach established by Imai and colleagues (e.g., Imai et al., 2011). This approach allows for the total effect of RCV to be decomposed into its direct $(X \rightarrow Y)$ and indirect $(X \rightarrow$ mediator $\rightarrow Y$ ) effects, as well as sensitivity analyses to be conducted. Results (reported in the Supplementary File, Appendix B, Table B6 and Figure B4) support the conclusion that only candidate contact mediates the relationship between RCV elections and increased youth turnout. The inclusion of the candidate contact covariate renders the interaction insignificant and, according to the decomposed RCV total effect, the indirect effect of RCV through candidate contact is roughly 12 percent of the full effect.

As additional robustness checks, all models from Tables 3 and 4 (and Table B6 in Appendix B) were re-estimated subsampling only those respondents under the age of 35 (see the Supplementary File, Appendix B, Tables B7.1 and B8, and Figure B5). Results strongly support the evidence provided here. There is no relationship between young voters, RCV elections, and candidate criticism or dissatisfaction with the candidates. Additionally, there is no link between campaign negativity and RCV elections. However, young voters in RCV elections are more likely to be contacted by candidates or campaigns than youths in plurality elections. Controlling for candidate contact reduces the RCV coefficient by nearly a third, though it remains statistically significant $(p=0.075)$. Further analyses using the non-parametric approach suggest the indirect effect of RCV through contact accounts for nearly a quarter of the total effect of $\mathrm{RCV}$ elections on youth voting. These results underscore the importance of candidate contact on mobilizing young voters in RCV elections.

\section{Summary and Conclusion}

Current literature suggests that preferential elections are less negative, with candidates less likely to criticize their opponents, more likely to reach out to voters, and citizens more likely to approve of campaigns (Bowler et al., 2003; Donovan et al., 2016; McGinn, 2020). At the same time, younger citizens are less likely to participate in politics due to their pessimistic political attitude and low levels of engagement (Dalton, 2015; Lawless \& Fox, 2015). Can RCV elections be the uplifting and mobilizing force young individuals need to push them into voting? The evidence presented here suggests so.

Comparing self-reported turnout between preferential and plurality cities matched on important demographics, we find strong evidence that younger individuals are more likely to vote in RCV cities compared to their younger counterparts in plurality cities. Further, the age gap in voting is much smaller in RCV cities, suggesting that RCV has the potential to decrease age inequality in the American electorate.

When it comes to why RCV elections motivate young voters to hit the booths, we find little support for any civility effects but strong support for potential mobilization effects. Little differences in perceived campaign civility were found, but young voters are significantly more likely to be contacted by a candidate/campaign than younger individuals in plurality cities. Further analyses reveal that candidate contact accounts for a substantial portion of the effect of RCV elections on youth voting, suggesting that increased candidate contact is a contributing factor behind increased youth voting in RCV elections. Last, it is worth mentioning that, across all models, the probability of older individuals voting rarely changes by more than a percentage point and is never statistically different from the probability of voting in plurality elections, providing further evidence that these effects may be more impactful on younger Americans.

\section{Acknowledgments}

We would like to thank the editors and reviewers for their constructive feedback.

\section{Conflict of Interests}

The authors declare no conflict of interests. 


\section{Supplementary Material}

Supplementary material for this article is available online in the format provided by the author (unedited).

\section{References}

Abramowitz, A. I., \& Webster, S. (2016). The rise of negative partisanship and the nationalization of US elections in the 21st century. Electoral Studies, 41, 12-22.

Baron, R. M., \& Kenny, D. A. (1986). The moderatormediator variable distinction in social psychological research: Conceptual, strategic, and statistical considerations. Journal of Personality and Social Psychology, 51(6), 1173-1182.

Bowler, S., \& Farrell, D. M. (1995). Voter strategies under preferential electoral systems: A single transferable vote mock ballot survey of London voters. British Elections and Parties Yearbook, 5(1), 14-31.

Bowler, S., Donovan, T., \& Brockington, D. (2003). Electoral reform and minority representation: Local experiments with alternative elections. Columbus, $\mathrm{OH}$ : Ohio State University Press.

Burnett, C. M., \& Kogan, V. (2015). Ballot (and voter) 'exhaustion' under instant runoff voting: An examination of four ranked-choice elections. Electoral Studies, 37, 41-49.

Dalton, R. J. (2008). Citizenship norms and the expansion of political participation. Political Studies, 56(1), 76-98.

Dalton, R. J. (2015). The good citizen: How a younger generation is reshaping American politics. Washington, DC: CQ press.

Dermody, J., \& Hanmer-Lloyd, S. (2004). Segmenting youth voting behaviour through trustingDistrusting relationships: A conceptual approach. International Journal of Nonprofit and Voluntary Sector Marketing, 9(3), 202-217.

Donovan, T., Tolbert, C., \& Gracey, K. (2016). Campaign civility under preferential and plurality voting. Electoral Studies, 42, 157-163.

Donovan, T., Tolbert, C., \& Gracey, K. (2019). Selfreported understanding of ranked-choice voting. Social Science Quarterly, 100(5), 1768-1776.

Drutman, L. (2020). Breaking the two-party doom loop: The case for multiparty democracy in America. Oxford: Oxford University Press.

Endres, K., \& Kelly, K. J. (2018). Does microtargeting matter? campaign contact strategies and young voters. Journal of Elections, Public Opinion and Parties, 28(1), 1-18.

FairVote. (2020). Data on ranked choice voting. FairVote. Retrieved from https://www.fairvote.org/data_on_ rcv\#research_snapshot

Farrell, D. M., \& McAllister, I. (2006). Voter satisfaction and electoral systems: Does preferential voting in candidate-centred systems make a difference? European Journal of Political Research, 45(5), 723-749.
Fortin, J. (2020). Why ranked-choice voting is having a moment. The New York Times. https://www. nytimes.com/2020/02/10/us/politics/rankedchoice-voting.html

Franklin, M. N. (2004). Voter turnout and the dynamics of electoral competition in established democracies since 1945. Cambridge: Cambridge University Press.

Gerber, A. S., \& Green, D. P. (2000). The effects of canvassing, telephone calls, and direct mail on voter turnout: A field experiment. American Political Science Review, 94(3), 653-663.

Green, D. P., \& Gerber, A. S. (2001). Getting out the youth vote: Results from randomized field experiments. Unpublished manuscript. Retrieved from http:// s3.amazonaws.com/fieldexperiments-papers2/ papers/00260.pdf

Green, D. P., Gerber, A. S., \& Nickerson, D. W. (2003a). Getting out the vote in local elections: Results from six door-to-door canvassing experiments. The Journal of Politics, 65(4), 1083-1096.

Green, D. P., Gerber, A. S., \& Nickerson, D. W. (2003b). The challenge of bringing voter mobilization 'to scale': An evaluation of youth vote's 2002 phone banking campaigns. New Haven, CT: Yale University, Institution for Social and Policy Studies.

Grofman, B., \& Feld, S. L. (2004). If you like the alternative vote (aka the instant runoff), then you ought to know about the coombs rule. Electoral Studies, 23(4), 641-659.

Grossmann, M., \& Hopkins, D. A. (2016). Asymmetric politics: Ideological Republicans and group interest Democrats. Oxford: Oxford University Press.

Hanmer, M. J. (2009). Discount voting: Voter registration reforms and their effects. Cambridge: Cambridge University Press.

Holbein, J. B., \& Hillygus, D. S. (2020). Making young voters: Converting civic attitudes into civic action. Cambridge: Cambridge University Press.

Horowitz, D. L. (2000). Ethnic groups in conflict, updated edition with a new preface. Berkeley, CA: University of California Press.

Imai, K., Keele, L., Tingley, D., \& Yamamoto, T. (2011). Unpacking the black box of causality: Learning about causal mechanisms from experimental and observational studies. American Political Science Review, 105(4), 765-789.

John, S., \& Douglas, A. (2017). Candidate civility and voter engagement in seven cities with ranked choice voting. National Civic Review, 106(1), 25-29.

Juelich, C. L., \& Coll, J. A. (2020). Rock the vote or block the vote? How the cost of voting affects the voting behavior of American youth. American Politics Research, 48(6), 719-724.

Kimball, D. C., \& Anthony, J. (2016). Voter participation with ranked choice voting in the united states. Paper presented at the Annual Meeting of the American Political Science Association, Philadelphia, United States. 
Kimball, D. C., \& Kropf, M. (2016). Voter competence with cumulative voting. Social Science Quarterly, 97(3), 619-635.

LaCombe, S. J., \& Juelich, C. (2019). Salient ballot measures and the millennial vote. Politics and Governance, $7(2), 198-212$.

Lawless, J. L., \& Fox, R. L. (2015). Running from office: Why young Americans are turned off to politics. Oxford: Oxford University Press.

Leighley, J. E., \& Nagler, J. (2013). Who votes now? Demographics, issues, inequality, and turnout in the United States. Princeton, NJ: Princeton University Press.

Levine, P., \& Lopez, M. H. (2002). Youth voter turnout has declined, by any measure. College Park, MD: Center for Information and Research on Civic Learning and Engagement.

Li, Q., Pomante, M. J., \& Schraufnagel, S. (2018). Cost of voting in the American states. Election Law Journal: Rules, Politics, and Policy, 17(3), 234-247.

Mason, L. (2018). Uncivil agreement: How politics became our identity. Chicago, IL: University of Chicago Press.

McDaniel, J. A. (2016). Writing the rules to rank the candidates: Examining the impact of instant runoff voting on racial group turnout in San Francisco mayoral elections. Journal of Urban Affairs, 38(3), 387-408.

McGinn, E. (2020). Rating rankings: Effect of instant runoff voting on participation and civility. Unpublished manuscript. Retrieved from http://eamonmcginn. com/papers/IRV_in_Minneapolis.pdf
Nickerson, D. W. (2006). Hunting the elusive young voter. Journal of Political Marketing, 5(3), 47-69.

Nielson, L. (2017). Ranked choice voting and attitudes toward democracy in the united states: Results from a survey experiment. Politics \& Policy, 45(4), 535-570.

Pew Research Center. (2019). Public trust in government: 1958-2019. Washington, DC: Pew Research Center. Retrieved from https://www.pewresearch.org/ politics/2019/04/11/public-trust-in-government1958-2019

Plutzer, E. (2002). Becoming a habitual voter: Inertia, resources, and growth in young adulthood. American Political Science Review, 96(1), 41-56.

Putnam, R. D. (2000). Bowling alone: The collapse and revival of American community. New York, NY: Simon and Schuster.

Reilly, B. (2002). Electoral systems for divided societies. Journal of Democracy, 13(2), 156-170.

Rosenstone, S. J., \& Hansen, J. M. (2003). Mobilization, participation, and democracy in America. Harlow: Longman Publishing Group.

Sloam, J. (2014). New voice, less equal: The civic and political engagement of young people in the united states and Europe. Comparative Political Studies, 47(5), 663-688.

Smith, H. (2016). FairVote civility report 7. FairVote. Retrieved from https://www.fairvote.org/rcv_and_ deliberative_engagement

\section{About the Authors}

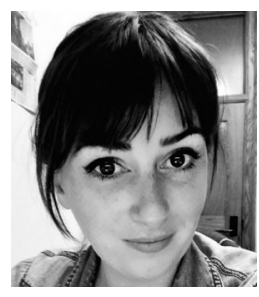

Courtney L. Juelich is an Assistant Professor of Political Science at the University of Wisconsin at Stout in the Department of Applied Social Science. Her research takes a unique approach to reassessing established theories of political participation and how they differ for the modern era and for younger citizens. In studying youth politics, her published papers and working papers look at how both institutional features like electoral systems, electoral laws, ballot initiatives, and behavioral features like gender, race, economic insecurity, and implicit biases shape people's political behavior. Her work has appeared in American Politics Research, Politics and Governance, and the Journal of Elections, Public Opinion and Parties. She received her PhD from the University of lowa, and an M.A. in Political Psychology from Stony Brook University.

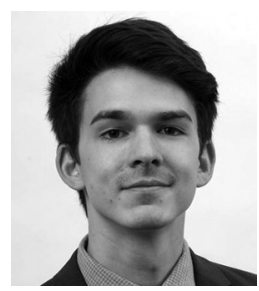

Joseph A. Coll is a Doctoral Candidate and instructor in the Political Science Department at the University of lowa. His research focuses on how election rules and administration shape the electoral behavior and representation of voters, primarily defined along age, ethnic, racial, and socioeconomic lines. His research interests also include political methodology, public policy, and public opinion. He has earned several awards and fellowships and his work has recently been published in American Politics Research, with works currently under review elsewhere. 